\title{
Temperament and schema-focused diagnosis in soft bipolarity
}

\author{
Elie Hantouche
}

\author{
From $1^{\text {st }}$ International Congress on Neurobiology and Clinical Psychopharmacology and European \\ Psychiatric Association Conference on Treatment Guidance \\ Thessaloniki, Greece. 19-22 November 2009
}

The current concept of Bipolar Spectrum is still evolving and much more interest is focused on the definition of Hypomania (BP-II Disorder) and especially Cyclothymic Disorder. In order to get the entire diagnosable range of bipolar conditions, the clinical approach must go beyond "polarity" of episodes: family history, age of onset, time course (circularity), level of recurrence, type of cyclicity (exogenous/endogenous), and especially affective temperaments. Clinical researches have been dedicated to explore affective temperaments and their role in psychopathology of mood disorders. Cyclothymia appears to be a likely precursor or a basic primary ingredient of the construct of soft bipolarity. The French studies directed by Hantouche and Akiskal showed that Cyclothymia is probably the most frequent expression of bipolar disorder, and represents a distinct entity with early onset, irritable ("dark") hypomania and high suicide risk. Despite these facts, there is a lot to learn about Cyclothymia. In the "psycho-education group therapy" model for Cyclothymia, elaborated in the CTAH, we recently addressed the following issues:

- Links between Cycothymic Temperament and Hypomania, dimensionally explored by the HCL-32 (Angst)

- Relationships between affective temperaments, especially Cyclothymic Temperament (assessed by TEMPS-A) and temperament (as measured by the Adult Temperament Questionnaire and the Affective Intensity Scale)

- Role of Cyclothymia in the "schema-focused approach" (J. Young)

- Expression of Cyclothymia through psychological vulnerabilities and interpersonal conflicts

Preliminary data will be presented.

Published: 22 April 2010

Director of CTAH, Anxiety and Mood Center, France

\section{References}

1. Hantouche E, Houyvet B: «Cyclothymie: Troubles bipolaires des enfants et adolescents au quotidien». Josette Lyon 2007.

2. Hantouche E, Blain R: «Cyclothymie pour le pire et le meilleur: bipolarité et créativité». Robert Laffont 2008.

3. Hantouche $E$, Trybou V: «Soigner sa cyclothymie: 7 clés pour retrouver l'équilibre de soi». Odile Jacob 2009.

doi:10.1186/1744-859X-9-S1-S78

Cite this article as: Hantouche: Temperament and schema-focused diagnosis in soft bipolarity. Annals of General Psychiatry 2010 9(Suppl 1): 578.
Submit your next manuscript to BioMed Central and take full advantage of:

- Convenient online submission

- Thorough peer review

- No space constraints or color figure charges

- Immediate publication on acceptance

- Inclusion in PubMed, CAS, Scopus and Google Scholar

- Research which is freely available for redistribution

Submit your manuscript at www.biomedcentral.com/submit
C Biomed Central 